山地小流域における溶存物質の降雨流出特性について（3）

Runoff of Dissolved Matters in Small Mountainous Watershed

$\begin{array}{llll}\text { 国立公害研究所 } & \text { 正員 } & \text { 平田健正 } & \text { T. Hirata } \\ \text { 国立公害研究所 } & \text { 正員 } & \text { 村岡浩爾 } & \text { K. Muraoka }\end{array}$

1・はじめに

筑波森林試験地（67.5ha）で観測された降雨流出時の溪流水質変化から、溶存物質の流出特性には 2 つのパターン、すなわち溪流水濃度について降雨終了後に浪降雨前のベース值に戻るType I とベース

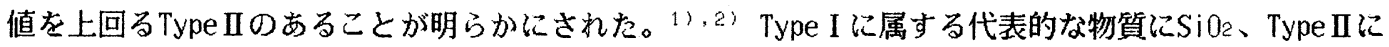
は $\mathrm{NO}_{3}$-Nがある。これらの物質の流出挙動の違いは中間流出成分、言い換えれば表層土壌水に含まれる 物質濃度に由来すると考えられ、筑波試験地で土壌水を採取し、土壌水質を調べてきた。るこれによる

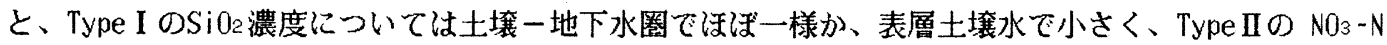
濃度は表層土壌水で高濃度で存在することが確認された。これらの結果は、概福溶存物質の降雨流出特 性から予測された土壌水質の鉛直分布と合致する。

他方、森林内では水分も含め物質埌土壌一植物体を通して常に循環している。入力としての降雨は樹 体と接触することによって林内雨や樹幹流となり、質・量共に変化して林床に到達する。さらに表層土 壌から植物体に吸収された養分量の約半分は 生長量として植物体に固定され、残りの半量 がリターとして林床に還元される。るまた林 内雨や樹幹流によって樹体から溶脱されて林 床に届く物質もある。したがって森林生態系 における物質循環に組名込まれた養分物質は 生熊系内を循環し易く、一方物質循環から外 れた物質は養分物質とは異なる移動特性を持 つと考えられる。こうした物質移動は最終的 に森林土㙵中の物質現存量やその鉛直分布、 ひいては土壤水筫や地下水質に反映されると 予想される。そこで森林生態系での物質循環 と土壌水質との関連を調べるために森林土壌 を採取し、元素分析を行った。この内、本研 究ではグ素と窒素を中心に、森林土滖中の 存在量や鉛直分布特性を明らかにし、土壌水 質やその流出の渓流水質に及ぼす影響につい て考察する。

2 . 溶存物筫の流出特性と土袞水筫

2.1 流出特性：ここでは降雨時に得られた溪 流水質資料から、溶存物質の流出特性をまと める。図 1 は総雨量48mmの降雨時に得られた 渓流水筫の経時変化であり、Type I とType II に区別して示す。同図下段に流量も描いてい る。大抵の物質は流量上昇期に濃度を減じ、 手減時に増加する。降雨流出の末期にほぼ降 雨前のベースレベルに回復するType I にはSi O2、 $\mathrm{Na}^{+} 、 \mathrm{Cl}^{-}$、電気伝導度SCが、ベースレベ

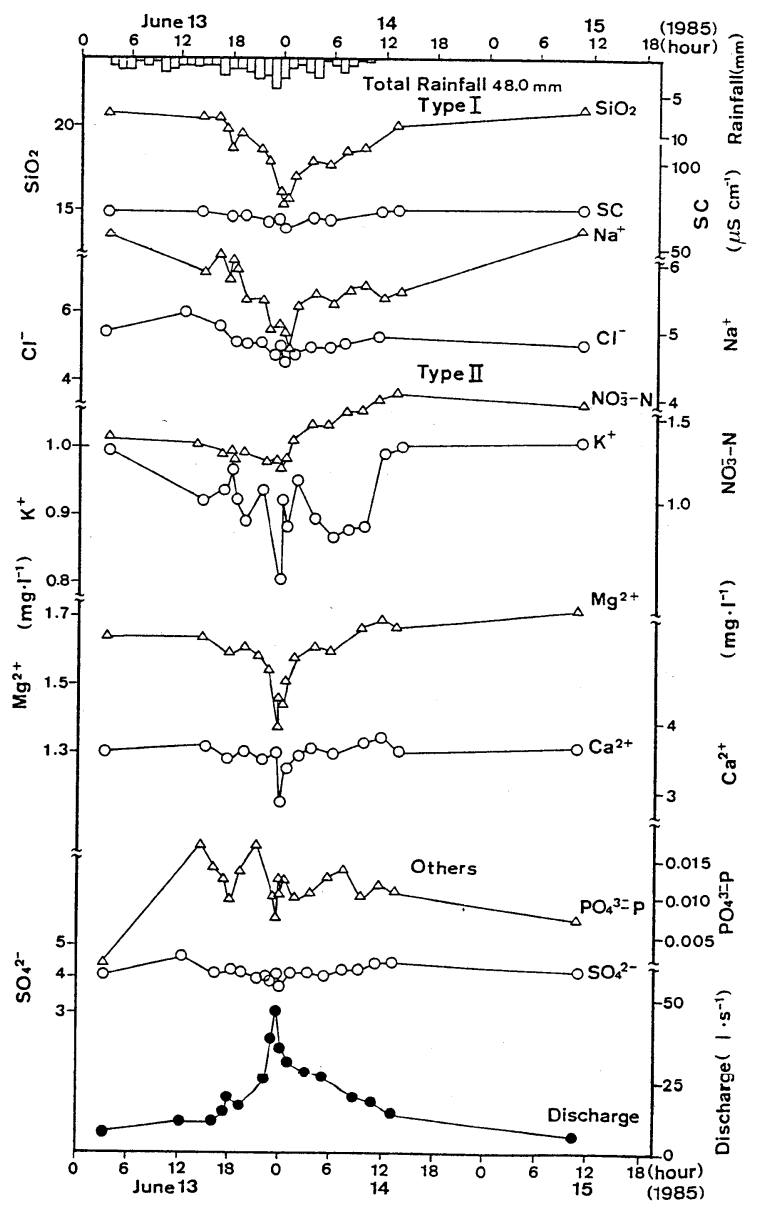

図 1 溶存物質の降雨流出特性 


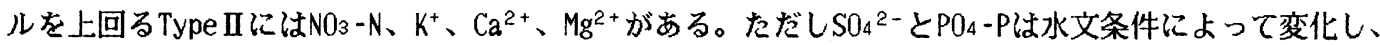
いずれとも分類し難い。こうした流出特性は図 1 以外の3つの降雨事象にも共通して認められた。4)降 水に含まれる物質湄度は溪流水のベース值より小さいことから、図 1 から推論されることは

1)流量上昇期の濃度減少は降雨成分に対応した表面流出成分による希釈効果である。

2)降雨終了後の渓流水は中間流出成分と地下水流出成分で構成されており、降雨流出時に地下水濃度が

変化しないならば、Type I とType II違いは中間流出成分と地下水に含まれる物質濃度に起因する。

3)Type I の物質については、中間流出成分と地下水で濃度に大差ないか、少なくとも中間流出成分で濃

度が小さく、他方Type IIでは中間流出成分で濃度が高まっていなければならない。

以上の考察から、表層土堙を中間流出の発現の場と捉え、森林試験地で土壌水を採取し、土壌水質の 鉛直分布と季節変化を調べてきた。

2.2 土堙水質：土㙵水は1986年2月から、ほぼ 2 週に一度の割合でスギ植林地内の 2 地点（引用文献 1) 内図 1 の 4 と B 4 地点) で鉛直方向に多点で採取している。採取深度は地表面から10、20、30、50、 75 （または95）、125、175cmの7点である。ここではType I のSi02、Type IIの N03-N濃度を取り挙げ、

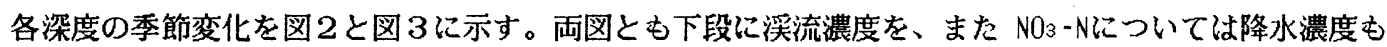
描いている。 $\mathrm{Si}_{2}$ は降水にほとんど含まれず、純粋に土培・岩石起源であり、樹木の代謝には何ら必要 とされない物質である。これに対し、N03-Nは降水や降下塺によって森林域にもたらされ、植物体の生 長に必要な多量必須元素であり、生態系内を循環し易い物質である。

$\mathrm{Si} 02$ は土袞母材を起源としており、したがって水の土壌との接触時間の長い程、壊度は高まることに なる。図 2 にある様に、深層の土䇎水程、SiO2濃度は高まっている。濃度変動幅も降雨流出の影響を受 けて、表層土壌水で大きくなっている。また1986年4月から1987年3月までのSi0 2 濃度の年平均値を見る こ、10cm深で $14.0 \mathrm{mg} / 1$ であるのに対し $175 \mathrm{~cm}$ 深では $21.9 \mathrm{mg} / 1$ であり、175cm深の值は渓流水の年平均值 21 $.7 \mathrm{mg} / 1$ に近い。

$\mathrm{NO}_{3}$ - $\mathrm{N}$ 濃度は $\mathrm{Si}_{2}$ 濃度とは逆に、表層土壌水で高まっている。窒素は本来、土壌や岩石に含まれない 物質であるが、土㙵形成過程でまず最初に大気中の窒素ガスが微生物によって土培中に固定される。

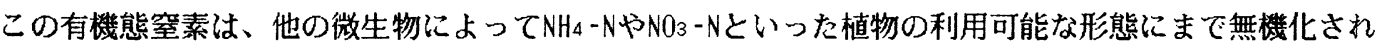
る。そして植物群落の発生とその遷移過程て、先に述べた養分物質の吸収・リターによる還元等の物質 循環に伴って、多量の窒素が表層土㙵中に蓄積されたと考えられている。 ${ }^{5}$ 図3を見ても、 $10 \mathrm{~cm} や 30 \mathrm{~cm}$

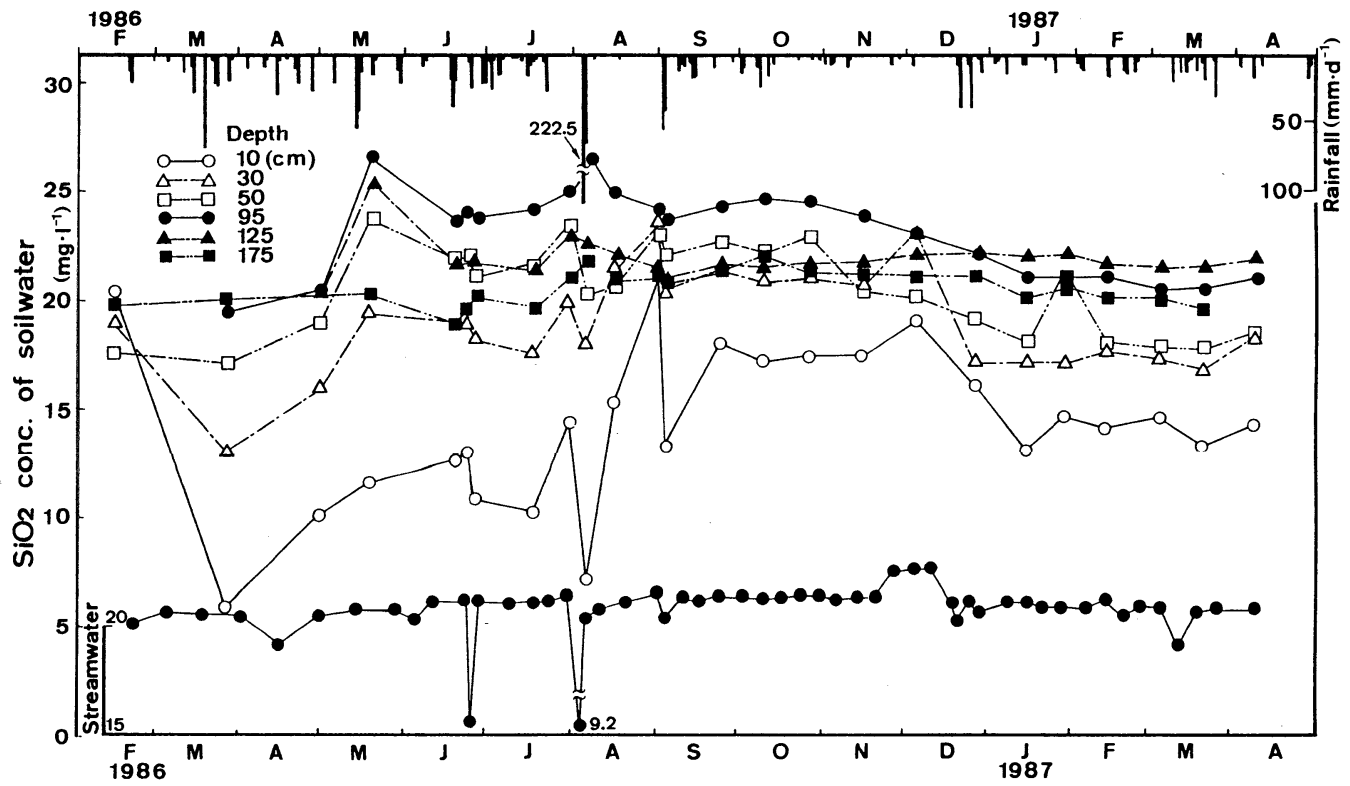

図 2 土袞水に含まれる $\mathrm{SiO}$ 襄度の季節変化 


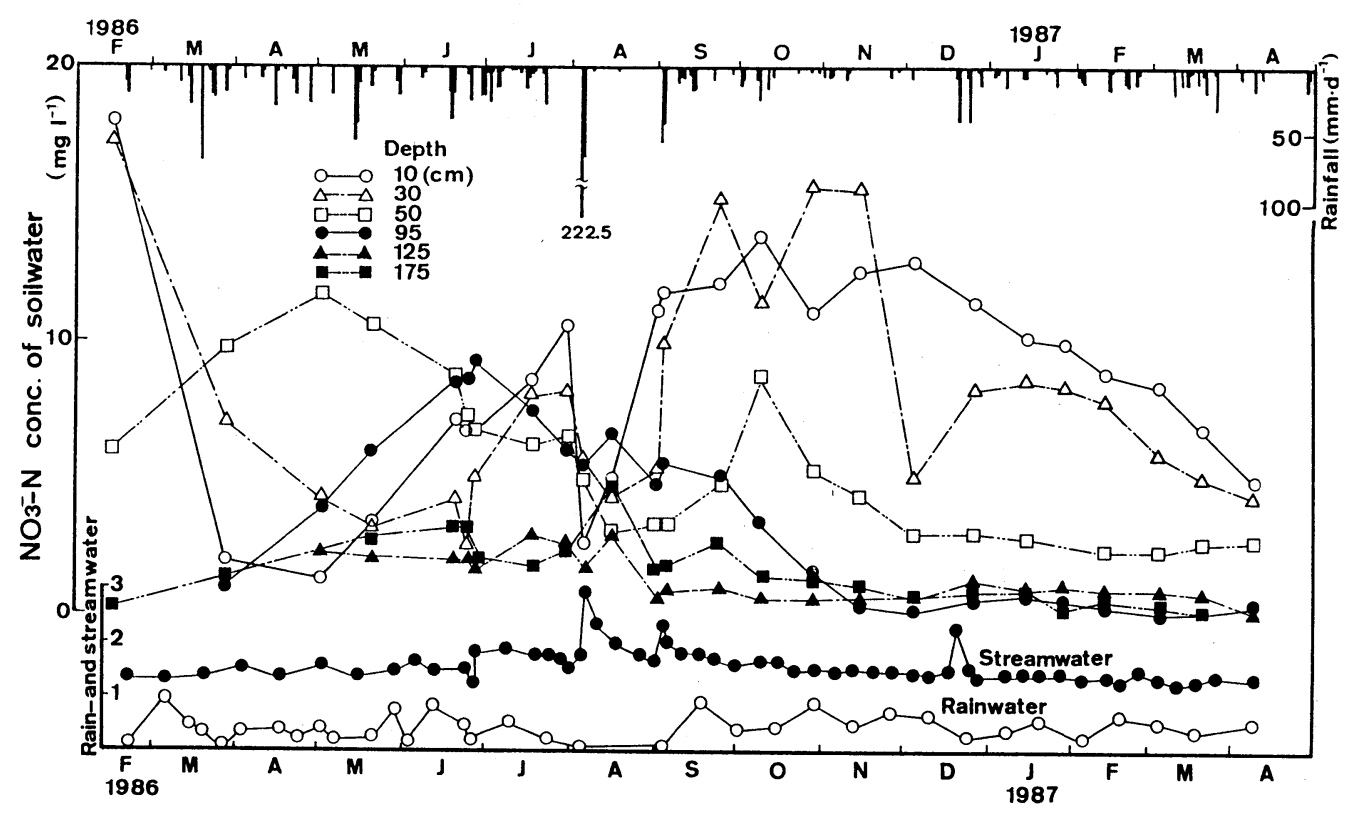

図3 土壤水に含まれる $\mathrm{NO}_{3}-\mathrm{N}$ 檂度の季節変化

深の $\mathrm{N}_{3}$ - $\mathrm{N}$ 濃度は極めて大きく変動しており、降雨流出による表層土壌からの溶脱だけでは説明できな い。1986年2月から5月にかけての $\mathrm{N} 03_{3}-\mathrm{N}$ 濃度の減少は降雨流出による溶脱であるにしてむ、5月から9月

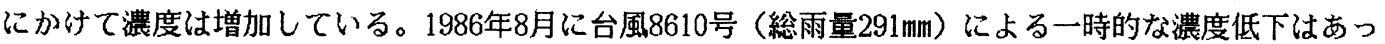
ても、依然として上昇傾向に変化はない。この春季から夏季にかけての表層土壌水の $\mathrm{NO}_{3}$ - $\mathrm{N} の$ 高まりは、 温度上昇により、森林土壌に含まれる有機態窒素の微生物分解が促進された結果と考えられる。一般に 温度が $10^{\circ} \mathrm{C}$ 上昇すると、分解速度は 2 倍になることが知られている。 ${ }^{6}$ 秋季から冬季にかけて高濃度を 維持する。冬季から春季にかけて微生物分解が進まないことから、降雨流出があれば $\mathrm{NO}_{3}$ - $\mathrm{N}$ 濃度は減少 する一方となる。これらの季節変化が図3に描かれている。また $\mathrm{N} 03_{3}-\mathrm{N}$ 蕽度の年平均値を見ると、10cm 深で8.3mg/1、175cm深で $1.42 \mathrm{mg} / 1$ となり、前者は後者の5.8倍にもなる。また $175 \mathrm{~cm}$ 深の値は溪流水の年 平均値1.77mg//と大きく違わない。

\section{3. 森林土壌中のケイ素と窒素の存在量}

3.1 土壤の採取と分析：森林土壌中に存在する物質量を求めるため、1987年3月20日に筑波森林試験地

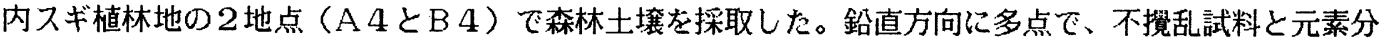
析用の筧乱試料である。採取地点む含めその周辺で、A日層は $1 \mathrm{~cm}$ 程度か、それ以下であった。また表層 土缺は黒味を帯びた褐色森林土壤で、樹木の毛根が多い。2地点共に $25 \mathrm{~cm}$ 深位から色調が変化し始め、 $30 \mathrm{~cm}$ 梁で灰色がかった小石混じりの土㙵となる。1 m深まで断面を切ったが、土袞の母材となるレキ類は 出なかったことから、地表面から30cm深まではA層、それ以下はB層と考えられる。

元素分析用の土㙵は $40^{\circ} \mathrm{C}$ で 1 昼夜乾燥させ、毛根などの植物遺体を除去した後、乳鉢で粉砕する。そ の後に $40^{\circ} \mathrm{C}$ で再度 4 日間乾燥させる。そうすることによって、試料の含水比は $1 \%$ \%ととなり、ここで 述べる物質存在量については水分の補正は行っていない。土壤中のケイ素量は試料をアルカリ熔融し、

7) $1 ： 1$ の HClで溶解した後、その試水を原子吸光法（島津AA-640-12）で定量した。窒素量はCNコー ダー(Yanaco MT500) で分析した。

3.2 ケイ素と窒素の存在量：土壌中のケイ素（Si）と窒素（N）の含有率を図4に、また有機物量の目 安として炭素(C)と強熱隇量を図5に示す。含有率は土壤乾重に対する割合である。

ケイ素について、2地点共表層て含有率は低下しており、腐植物の多いA層の特徴を示している。20 cm以深で、B 4 地点でわずかに減少するものの、全体として深さ方向に漸增する様である。また筑波森 
林試験地のケイ素の含有率は $23.9 \%$ から $38.1 \%$ 範囲にあり、一般に土 壤に含まれるケイ素量25〜41\% ${ }^{81}$ おさまっており、ほぼ妥当な結果と 言える。

窒素については、その含有率は明 らかに深さ方向に減少している。B 4 地点について、表層 $5 \mathrm{~cm}$ 深で 0.5 $2 \%$ 含有率が $95 \mathrm{~cm}$ 深で0.017\%とな り、1/30にまで減少する。またケイ 素の合有率の高いB 4地点で、窒素 の含有率はA 4 地点に比べて小さく なっている。深度 $1 \mathrm{~m}$ での窒素の 存在量を求めると B 4地点で 10.2 to n/ha、A 4 地点で19.1ton/haであり、 平均すると $14.7 \mathrm{ton} / \mathrm{ha}$ となる。因に 降雨によって森林試験地にもたらさ れる窒素は年間 $12.7 \mathrm{~kg} / \mathrm{ha}$ 、生長に 伴って植物体に固定さ れる量は21.7 kg/haで ある。9 従って森林生 態系を循環する窒素の 約 700倍にも上る膨大 な量が、森林の表層土 㙵に蓄積されているこ とになる。

図5は土堙中に含ま れる有機物量の指標と なる炭素の含有率と強 熱減量を描いているが、 いずれむ窒素と同様表 層土壌で高く、深さと 共に減少する。特に15 cm深までの減少率が大 きく、極く表層に多量

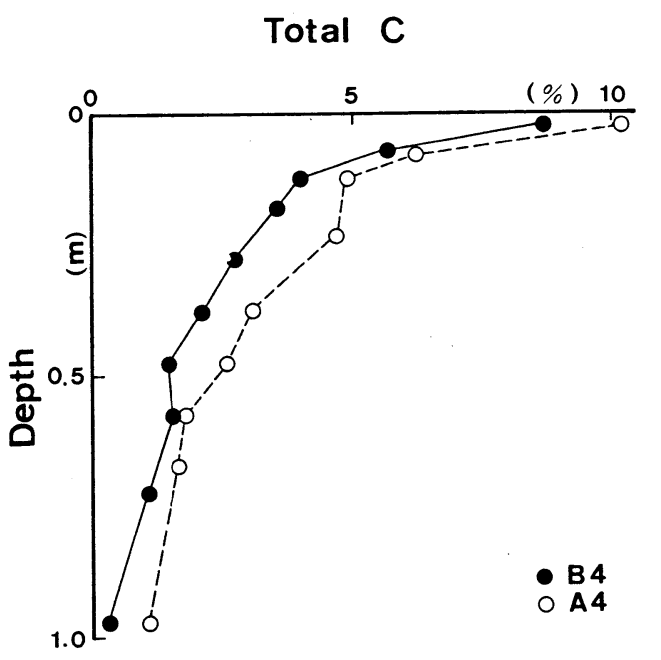

Total C

図4 森林土袞のケイ素と窒素の含有率

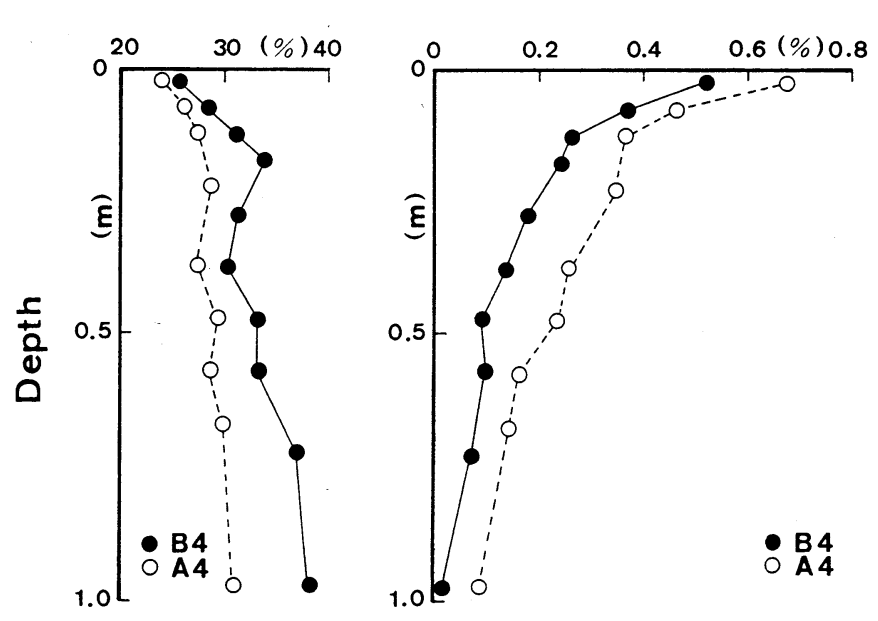

の有機物の存在する事が理解できる。また有機物量の多いほど、ケイ素の含有率は低く、森林土境の形 成過程もうかがえる。

土壤中の物質の存在量や鉛直分布形は、直ちに土培水質と結びつくものではない。ケイ素にしても全 てが溶存ケイ酸（ $\mathrm{Si}_{2}$ ）ではなく、窒素については大部分が有機態であり、そのままでは水に溶けない。 さらに、水と土壤との接触時間や微生物の介在と言った定量困難で、しかも環境中で変動の大きい要素 むある。しかしながら水が接している土壌中の物質存在量は、土壌水質を決定する最大の要因であるこ とに違いはない。実際に、図4に描かれた森林土塂のケイ素と窒素の含有率の鉛直分布は、図 2 と図 3 にある土壌水の $\mathrm{SiO}_{2}$ 濃度及びN03-N濃度の鉛直分布と矛盾しない。

さらに図6は森林土袞の採取と同じ1987年3月20日に得られた土壤水のSi02 濃度と $\mathrm{NO}_{3}-\mathrm{N}$ 濃度である。

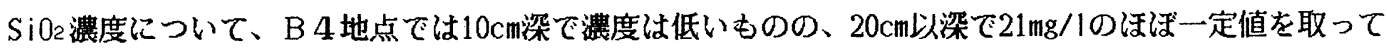
いる。また A 4 地点では深さと共に増加傾向にあり、175cm深で20mg/1の值となる。両者の澧度值に違 
いが認められるが、これは 図4にある土壌中のケイ素 の存在量の差が反映された 結果とみられる。 $\mathrm{NO}_{3}$ - $\mathrm{N}$ 濃 度は鉛直分布に違いはあっ てむ、50cm以浅で高濃度を 維持している。

4.まとめ

森林域からの溶存物質の 流出機構を調べる目的で、 1984年9月以来筑波山系に 設けた $67.5 \mathrm{ha}$ の森林試験地 において、降雨・林内雨 ・ 土㙴水・地下水・溪流水と 言った水移動に伴う水質の 変化を観測してきた。特に 降雨時の溪流水筫の変化か ら、溶存物筫の流出パター ンには 2 つタイプのある
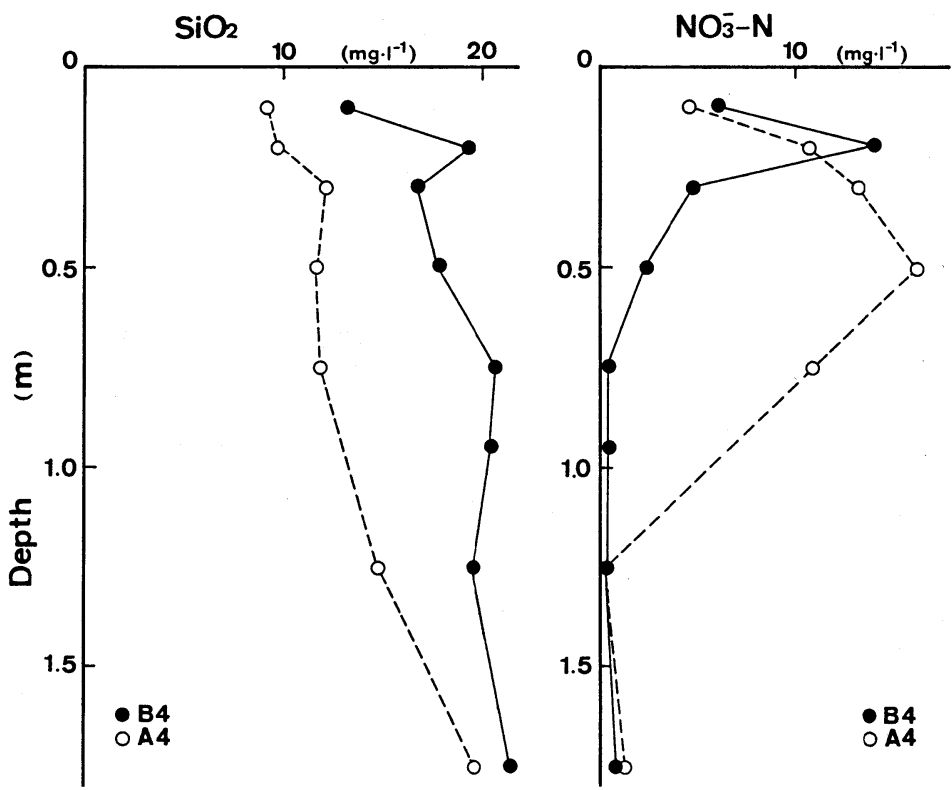

図6 土㖶水のSiO2と $\mathrm{NO}_{3}-\mathrm{N}$ 檂度の鉛直分布（1987年3月20日）

ことが見出された。降雨終

了後に降雨前のベース值に回復するType I とベース値を上回るType II である。こうした流出特性の違い は、降雨終了後の溪流水の構成成分から判断して、中間流出成分、言い換えれば表層土壌水の流出に由 来すると考え、土㙋水質の分布特性が調べられた。

中でも著者らはType I に属する $\mathrm{Si}_{2}$ とType II $\mathrm{NN}_{3}-\mathrm{N}$ の挙動は水分も含めた物質の流出機構を解明す る上で、重要な手掛りになると考えている。既述の様に、両者は降雨時の水質時系列において、また土 蚈水質でも際立った違いを見せる。こうした差異を説明するには、水質そのものの観測は勿論、水質変 化を引き起こす物質の起源にまで立ち入る必要がある。この時、Si 02 は降雨にはほとんど含まれず、純 粋に土墥起源の物質であること、一方 $\mathrm{NO}_{3}$ - $\mathrm{N}$ は降水にも含まれ、また養分物筫でもあるから森林内を循 環する物質であることに注意を要する。すなわち、物質循環に組み込まれた物質と外れた物質とでは、 森林生態糸ての移動特性が大きく異なるからである。事実、森林土壌中のケイ素と窒素の存在量を調べ ると、採取地点で鉛直分布に違いはあっても、1)土㙵のケイ素合有率は表層で小さく、深さ方向に増加 すること、2)森林表層土䇎に極めて多量の窒素が蓄積されていること、が確認された。これは森林生態 系における物質循環特性が土壤中の物質存在量に反映され、土䁃水質、ひいてはその流出によって渓流 水筫の形成に大きく影響していることを表わしている。

図 7 は降雨、林内雨、土袞水、地下水、渓流水の順に、森林生態系での鉛直水移動に伴う水質変化を 描いている。10) 資料は1986年4月から1987年3月までの年平均值であり、溶存物質の流出特性から分類 されたType I とType II に区別して描いている。眐述の様に、Si $0_{2}$ は土壌岩石起源の物質であることから、 降雨・林内雨にはほとんど含まれず、その濃度は土釷と接することによって著しく高まる。これ以外の 物質についても、降雨・林内雨・土袞表層へと移行するに伴って濃度は高まり、中でも林内雨のK+は樹 体加ら溶出もあって濃度は大きく增加する。土壤表層から溪流水の間で、Type I に分類される物質濃

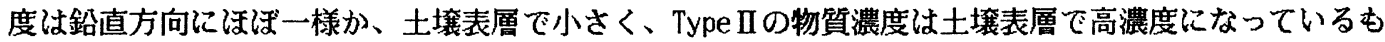
のが多い。さらに特徴的なことは、 $\mathrm{NO}_{3}-\mathrm{N}$ 含めてType IIに分類された物質は全て、植物体にとっての 多量必須元素に属することである。森林生態系の物質循環に組み込まれることによって、これらの物質

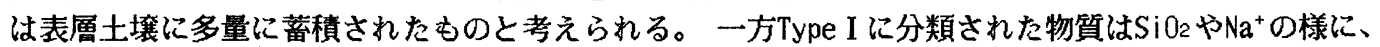
植物の代謝には必要とされない物質か、C1-の様に必須ではあっても微量元素に属する物質である。ケ 

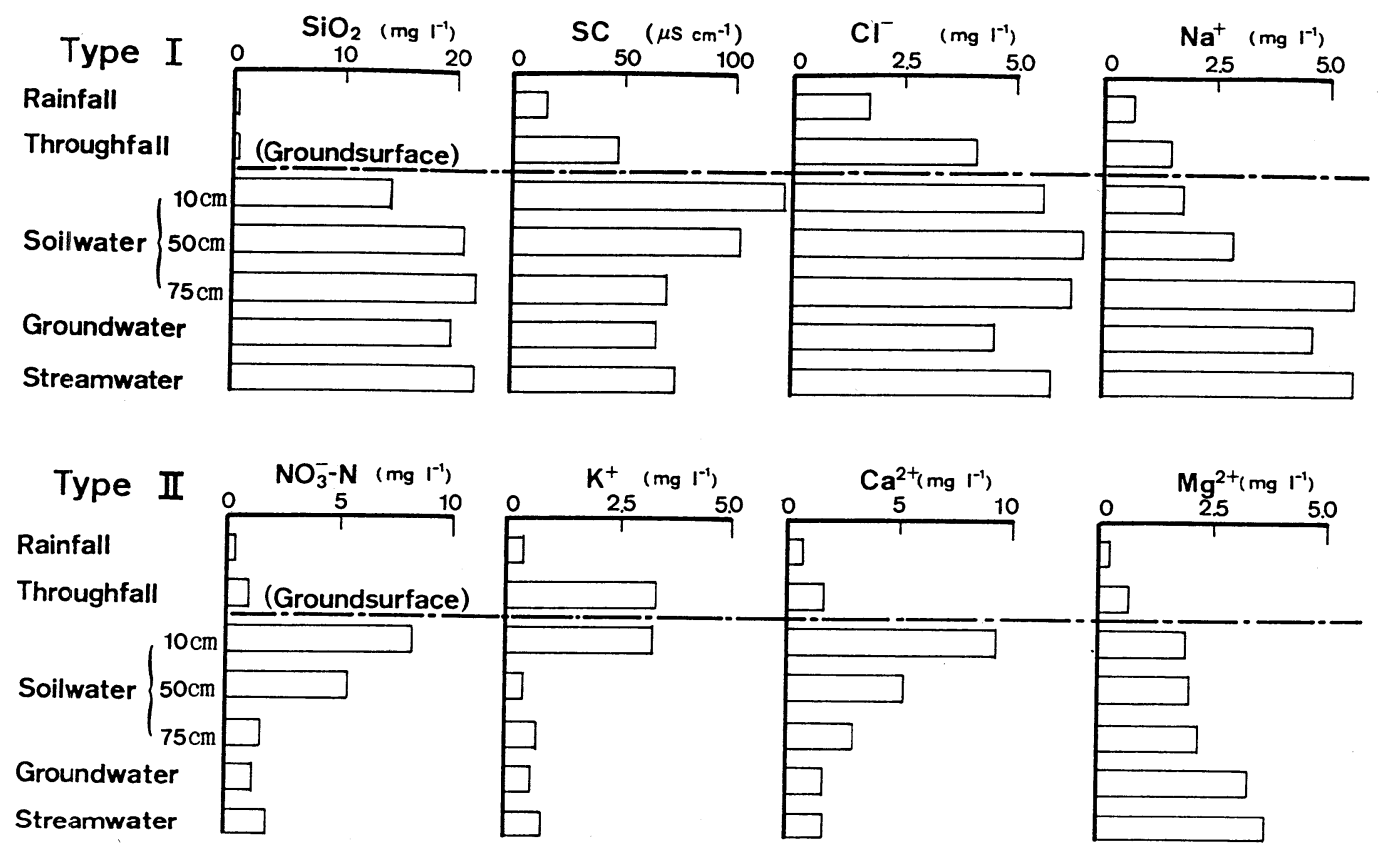

図7 水移動に伴う水筫の変化

イ素や窒素以外の物質についても、土壤中の存在量やその鉛直分布形は、それぞれの物質の森林生態系 における移動特性を反映していると予想される。森林生態系での物質循環は調查にかなりの困難を伴う が、水のみを対象とした時、欠如しがちであった流域特性について新たな知見が期待できる。

最後に、本研究の一部は文部省科学研究費 - 環境科学特別研究 (代表者 滋賀県立短大助教授 国松 孝男) の助成を得て行われたことを記す。

\section{引用 文 献}

1) 平田健正・村岡浩爾(1986)：山地小流域における溶存物質の降雨流出特性について. 第30回水講論文 集, 43-48.

2）平田健正・村岡浩爾(1987)：山地小流域における溶存物質の降雨流出特性について（2）. 第31回水 講論文集, 59-64.

3）岩坪五郎(1976)：森林生態系での植物養分物質の循環. 山岳・森林・生態学, 今西綿司博士古稀記念 論文集，中央公論社，313-360.

4）平田健正・村岡浩爾(1988)：溪流水質からみた森林の浄化機能に関する研究（第3報）溶存物質の流 出機構. 国公研報告. (印刷中)

5) 大政正隆著(1977)：土の科学. NH Kブックス，48-64.

6）河原輝彦 (1976)：リタ一の分解（IV）土壌呼吸量中の根の呼吸量の推定. 日林誌，58(10)，353-359.

7）渋谷政夫 - 小山雄生・渡辺久男共著(1978)：重金属測定法. 博友社，17-19.

8) Bowen, H. J. M. (1979): Environmental Chemistry of The Elements. Academic Press, 60-61.

9）村岡浩爾・平田健正(1988)：溪流水質から見た森林の浄化機能に関する研究（第4 報）. 水収支と物 質収支，国公研報告.（印刷中）

10)Muraoka, K. and T. Hirata (1988): Streamwater chemistry during rainfall events in a forested basin. J. Hydrology. (in press) 